\title{
Geospatial Analysis and Turbidity Measurement for Monitoring Suspended Solids of Hitotsuse Dam in Miyazaki Prefecture, Kyushu, Japan
}

\author{
Purnama Budi Santosa ${ }^{1}$, Yasuhiro Mitani ${ }^{2}$ \\ ${ }^{1)}$ Dept. of Geodetic Engineering, Faculty of Engineering, Gadjah Mada University \\ ${ }^{2}$ Dept. of Civil \& Structural Engineering, Faculty of Engineering, Kyushu University, Japan \\ Corresponding Email: purnamabs@ugm.ac.id
}

\begin{abstract}
The existence of suspended solids at Hitotsuse dam, Miyazaki Prefecture, Kyushu, Japan, has been the main concern of Kyushu Electric Power Company. These have been carried by rivers flowing into the dam. In a long term, it is worried that this phenomenon will potentially cause the environmental degradation, especially around the dam, where the Kyushu Electric Power Plant is located. Therefore, necessary measures are required to protect the dam from environmental degradation, which in return is to assure its long term power plant operational. Preliminary studies found that the suspended solids, which was generated upstreams and was carried out into the dam by rivers, causes the turbid water resident. Therefore, evaluation on the potential sources of the existence of the suspended solids needs to be carried out. In this research, analysis was conducted to figure out the spatial distribution and the quantity of the suspended solids. For this purpose, by focusing attention on the upper river basin of reservoir, several factors which are possible to cause turbid water are extracted and analyzed quantitatively by using GIS. To understand the characteristic of the river turbidity, river flows and river turbidity are measured at several selected stations. Then mechanical factors causing turbid water are identified after analyzing relationship between efflux characteristics and possible factors that induce the presence of suspended solids. The results show that spatial information extraction could be done efficiently by applying spatial analysis method. Furthermore, by applying multiple regression analysis, it was found that landslide scars, artificial forests, drainage area, and terrain undulation are indicated as the dominant factors causing the turbidity.
\end{abstract}

Keywords: GIS, river turbidity, suspended solids, hydrology, watershed

\begin{abstract}
Abstrak
Keberadaan padatatan tersuspensi di dam Hitotsuse, Prefektur Miyazaki, Kyushu, Jepang, telah menjadi perhatian utama dari Perusahaan Listrik Kyushu. Material padat ini dibawa oleh sungai-sungai yang mengalir ke dalam dam. Untuk jangka panjang, dikhawatirkan fenomena ini berpotensi akan menyebabkan degradasi lingkungan, terutama di sekitar dam, di mana Perusahaan Listrik Kyushu berada. Oleh karena itu, diperlukan langkahlangkah yang diperlukan untuk melindungi dam dari degradasi lingkungan, dan untuk operasional pembangkit listrik untuk jangka panjang. Penelitian awal menemukan bahwa padatan tersuspensi, yang berasal dari hulu bagian atas daerah aliran sungai dan terbawa masuk ke dam melalui sungai-sungai, menyebabkan keruhnya air dam. Oleh karena itu, evaluasi terhadap sumber-sumber potensial keberadaan padatan tersuspensi ini perlu dilakukan. Dalam penelitian ini, analisis dilakukan untuk mengetahui distribusi spasial dan kuantitas padatan tersuspensi. Untuk tujuan ini, dengan memfokuskan perhatian pada DAS bagian atas reservoir, beberapa faktor yang mungkin menyebabkan air keruh diolah dan dianalisis secara kuantitatif dengan menggunakan SIG. Untuk memahami karakteristik dari kekeruhan sungai, arus sungai dan kekeruhan sungai diukur dengan beberapa stasiun yang dipilih. Kemudian faktor mekanik yang menyebabkan air keruh diidentifikasi setelah menganalisis hubungan antara karakteristik efflux dan kemungkinan faktor padatan tersuspensi. Hasil penelitian menunjukkan bahwa ekstraksi informasi spasial dapat dilakukan secara efisien dengan menerapkan metode analisis spasial. Selanjutnya, dengan menerapkan analisis regresi berganda, ditemukan bahwa longsor dan hutan buatan, wilayah drainase, dan terain bergelombang diindikasikan sebagai faktor dominan yang menyebabkan kekeruhan.
\end{abstract}

Kata kunci: SIG, kekeruhan sungai, padatan tersuspensi, hidrologi, DAS 


\section{Introduction}

Kyushu electric power plant which is located in the Hitotsuse dam, in Miyazaki Prefecture is one of the main electric power plants managed by Kyushu Electric Power Plant Company. The water in this dam is supplied from the rivers flowing from the upper basins. During several recent years, the environmental degradation problem has been the concern of the company. One of the sources of the problem is the existence of turbid water from the upper rivers which can potentially causes the existence of suspended solids at Hitotsuse dam. In a long term, it is worried that this phenomenon will potentially cause the environmental degradation, especially around the dam, where the Kyushu Electric Power Plant is located. Therefore, necessary measures are required to secure the dam from environmental degradation, which in return is to assure the long term power plant operational activities.

Stream water substance is controlled by numerous natural and anthropogenic factors (Ahearn et al., 2005). Their effects on hydrochemistry can either be diffuses (e.g., runoff from urban and crop cultivation, interflow through organic rich soils) or point pollutants (e.g., industrial effluents) (Sliva and Williams, 2001; Li etal., 2008).Also, watershed characteristics including topography and surficial geology can influence surface water quality (Sliva and Williams, 2001). In recent years there is a rapid declining availability of usable freshwater in terms of water quality and quantity due to unsustainable land use practices (Ngoye and Machiwa, 2004). Water quality is generally linked to land use/land cover (LULC) in catchment (Ahearn et al., 2005), and studies have been focusing on their relationships with water quality variables such as dissolved salts, suspended solids, and nutrients (Hill, 1981; Smart et al., 1998; Sliva and Williams, 2001; Turner and Rabalais, 2003; Ahearn et al., 2005). They conclude that agricultural land use strongly influences nitrogen (Smart et al., 1998; Ahearn et al., 2005), phosphorus (Hill, 1981), and sediments (Ahearn et al., 2005) in stream water. Urban land use has influenced water nutrients as well (Sliva and Williams, 2001).

Turbidity is a fundamental index used to assess water quality conditions. Turbidity in natural waters is typically caused by fine inorganic and organic particles suspended within the water column.Variations in turbidity also help us to understand the distribution of total suspended solids or sediments (TSS), as well as processes like coastal erosion and mobilization of chemicals or pollutants (Heyes et al., 2004). Researches and studies with focus on river turbidity have been a concern for some researchers (Chikita and Okumura, 1990; Pirmez and Imran, 2003; Pavanelli and Bigi, 2005; Lawler et al, 2006;; Foltz et al, 2007; Susfalk et al, 2008;). Lawler et al (2006) for example, conducted research on the analysis of turbidity dynamics during spring storm events in an urban headwater river system. A research on the calculation of sediment runoff values from a watershed has been demonstrated by Osawa et al (2003). This research develops a Suspended solids Contents (SSC) analysis model based on a storage-type and lumped parameter model, such as Tank Model, for a watershed with insufficient data collection, to calculate discharge and SSC at the end of the watershed. Sakai et al (2005) developed a storage-type sediment runoff model with two runoff elements of direct runoff and base runoff with the sediment runoff process corresponding to these runoff elements. This model is used to calculate SSC of two catchments in Okinawa with significant success.

Other researches which are focused on the utilization of satellite images for monitoring 
water turbidity has been carried out by many researchers (Chen et all, 2007; Bustamante et al, 2008; Stech et al, 2007). The utilization of this data is based on the fact that satelliteborne sensors is potentially to be an effective tool to assess turbidity because they provide synoptic and frequent mapping capabilities. However, satellite platforms also have limitations such as in spatial resolution, revisit time, accessibility to data, sensor calibration and image processing software.

By considering the turbidity problem characteristics in the Hitotsuse area, this study tries to develop a spatio-statistical analysis model which is based on GIS spatial analysis method and statistical approach to understand the potential factors which cause in the existence of turbidity in the river water. Hydrological Tank Model was utilized for river water turbidity based on input precipitation data as it proves to be potential for hydrological modeling.

\section{Study Area and Research Method}

Miyazaki Prefecture is located in south-east of Kyushu island, Japan, surrounded by Oita Prefecture on the north, Kumamoto Prefecture on the west, Kagoshima Prefecture on the south, and Pacific ocean on the east. The study area is in a mountainous forested terrain of the Hitotsuse area in Miyazaki Prefecture, Kyushu (Figure 1), bounded within Latitude: $32^{\circ} 10^{\prime} 48^{\prime \prime} \mathrm{N}-32^{\circ} 24^{\prime} 59^{\prime \prime} \mathrm{N}$ and Longitude: $131^{0} 2^{\prime} 40^{\prime \prime} \mathrm{E}-131^{0} 17^{\prime} 31^{\prime \prime} \mathrm{E}$. The topographic condition is very undulating with maximum slope of about 79.5 degrees, and the elevations ranging from 196 to $1723 \mathrm{~m}$ above sea level. The natural vegetation is warm-temperate evergreen broadleaf forest and secondary natural broadleaf forest presently dominates the area.

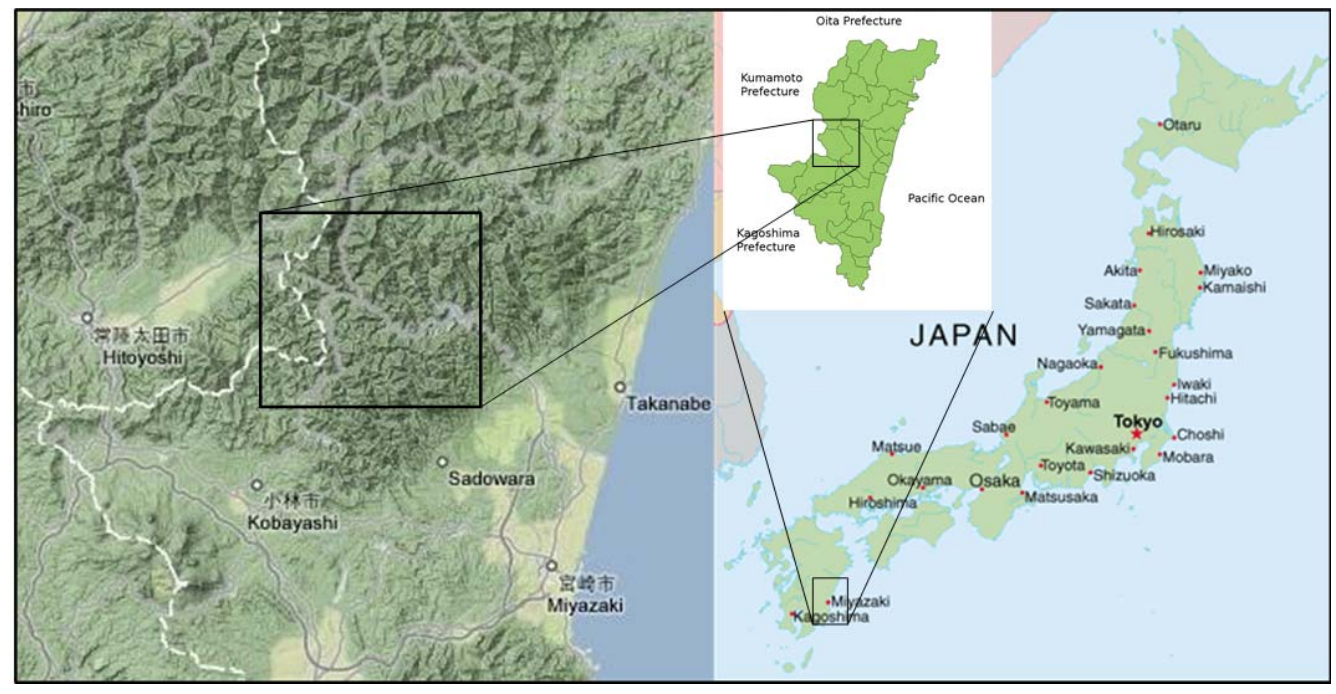

Figure 1. Study location in Hitotsuse area, Miyazaki Prefecture, Japan

The data used in this study are SPOT satellite data, digital elevation model (DEM), precipitation, and river turbidity data. A SPOT $5 / \mathrm{HRG}$ image was utilized in this study. This satellite data was observed in February 3, 2006 and November 11, 2006. They have four bands: band 1 (visible green, 0.50-0.59 $\mu \mathrm{m}$ ), band 2 (visible red, 0.61-0.68 $\mu \mathrm{m}$ ), band 3 (near-infrared, $0.78-0.89 \mu \mathrm{m}$ ), and band 4 (SWIR, 1.58-1.75 $\mu \mathrm{m}$ ). The spatial resolution of band 1 to band 3 is $10 \mathrm{~m}$, and band 4 is $20 \mathrm{~m}$. A $10-\mathrm{m}$ grid digital map created by Hokkaido Map Corporation was used for the digital elevation model (DEM). This DEM was produced based on digital 10 $m$ contour map at scale 1:25000 published by the Geographical Survey Institute of Japan. The river turbidity and river flow data was measured at a period of time for each of the selected sites or observation stations (table 1). Whereas the precipitation data $(\mathrm{mm} / \mathrm{h})$ 
collected from 9 stations: Oukawachi, Oyabu, Kamiitaya. The recorded data was dated from Makinokuchi, Kamiage, Ohae, Ogawa, 2006/5/1 (10:00) to 2006/10/16 (18:00) and Murasho power station, Murasho, and from 2007/4/1 (10:00) to 2007/11/25 (00:00).

Table 1. River turbidity and river flow data observation period.

\begin{tabular}{clc}
\hline Station & \multicolumn{1}{c}{ Turbidity $(\mathrm{ppm})$} & Flow $(\mathrm{m} 3 / \mathrm{s})$ \\
\hline & $2006 / 4 / 2814: 00-2006 / 7 / 612: 00$ & \\
H26 & $2006 / 8 / 320: 00-2006 / 9 / 515: 00$ & $2007 / 9 / 416: 00-2007 / 11 / 7$ 9:00 \\
& $2007 / 6 / 2010: 00-2007 / 8 / 2411: 00$ & \\
& $2007 / 9 / 416: 00-2007 / 11 / 1510: 00$ & \\
& $2006 / 4 / 2814: 00-2006 / 9 / 68: 00$ & \\
H31 & $2007 / 6 / 2010: 00-2007 / 8 / 2316: 00$ & $2007 / 9 / 416: 00-2007 / 11 / 79: 00$ \\
& $2007 / 9 / 1416: 00-2007 / 11 / 1415: 00$ & \\
H29 & $2007 / 6 / 2010: 00-2007 / 11 / 1415: 00$ & $2007 / 9 / 416: 00-2007 / 11 / 79: 00$ \\
H21 & $2007 / 6 / 2010: 00-2007 / 8 / 1413: 00$ & $2007 / 9 / 416: 00-2007 / 11 / 78: 00$ \\
& $2007 / 9 / 416: 00-2007 / 11 / 1412: 00$ & \\
H28 & $2007 / 9 / 1416: 00-2007 / 11 / 1415: 00$ & $2007 / 9 / 1416: 00-2007 / 11 / 79: 00$ \\
H22 & $2007 / 9 / 1416: 00-2007 / 11 / 1415: 00$ & \\
& $2007 / 9 / 199: 00-2007 / 11 / 1414: 00$ & $2007 / 9 / 416: 00-2007 / 10 / 216: 00$ \\
H36 & $2007 / 6 / 2010: 00-2007 / 8 / 2415: 00$ & $2007 / 9 / 416: 00-2007 / 11 / 79: 00$ \\
& $2007 / 9 / 416: 00-2007 / 11 / 1514: 00$ & \\
H37 & $2007 / 6 / 2010: 00-2007 / 8 / 2415: 00$ & $2007 / 9 / 416: 00-2007 / 11 / 79: 00$ \\
\hline
\end{tabular}

The research flow is grouped into three steps: based on spatial analysis method within GIS. 1) spatial information extraction and analysis, The extracted and developed spatial data are 2) river water flow and turbidity observation the factors which are potentially contribute and analysis, and precipitation data collection, to the existence of river turbidity, which and 3) statistical analysis. Spatial information then are called mechanical factors. These extraction and analysis includes steps of identified mechanical factors are described in preparation and development of spatial data table 2, which are grouped into five types of necessary for the analysis. This was done contributing factors.

Table 2. Type of mechanical factors.

\begin{tabular}{cl}
\hline Type of contributing factors & \multicolumn{1}{c}{ Mechanical factors } \\
\hline Hydrological factor & $\begin{array}{l}\text { Drainage area, river length, river density, curvature of } \\
\text { river, stream gradient } \\
\text { Average of slope angle, dip direction, slope number } \\
\text { and density, terrain undulation, failed slope }\end{array}$ \\
Geological and edaphic factor & Geologic condition, soil type \\
Land cover & Land cover class, land cover change, landslide scar \\
Man-caused factor & Area of artificial forest, road density
\end{tabular}


The river flow and turbidity observation was done by measuring the river flow and its turbidity within a period of time at eight selected stations (see table 1). These stations were selected based on the turbidity currents which were identified from the previous study. Then, based on the previously developed tank model system, the collected precipitation data, river flow data, and turbidity data were utilized to develop a hydrological model of the study area. This model was used to predict the turbidity currents under specific precipitation input data, namely $10 \mathrm{~mm} / \mathrm{h}, 20 \mathrm{~mm} / \mathrm{h}$ and $30 \mathrm{~mm} / \mathrm{h}$. The resulting turbidity currents which were predicted under specific rainfall circumstances were then utilized to identify the correlation between the mechanical factors and the turbidity currents by utilizing multiple regression analysis.

\section{Results and Discussion}

The developed spatial database which is necessary for conducting the analysis comprises of several data which are identified as mechanical factors. These mechanical factors are believed to be the contributing factors for the occurrence of the suspended material in river turbidity. Some of these mechanical factors are depicted in figure 2. Figure $2 \mathrm{a}$ shows the four watersheds namely Hitotsuse, Itaya, Ogawa, and Shiromi watershed, also eight selected observation stations for the purpose of turbidity and river flow data collection which are located in the Hitotsuse watershed. Each of these stations represents its catchment. The stations selection was based on the previously recorded turbidity data which showed the significant high quantity of the suspended solids contents within the water column.

For the hydrological factor data, the extracted information is drainage area, river length, river density, curvature of river, and stream gradient. These hydrological factor data were extracted from DEM(Digital Elevation Model) and river networks. Drainage area represents the catchment area, which was created by using ArcHydro tools within ArcGIS. For the purpose of analysis, the river length, river density, river curvature and stream gradient are extracted within the analysis unit of catchment. The DEM was also the main data for the purpose of topographical factor data, which include average of slope angle, dip direction, slope number and density, terrain undulation, and failed slopes. Average of slope angle (or average inclination) is the average inclination angle which was calculated from slope units within the analysis unit. The dip direction (inclined direction) is the majority of inclined direction (represented by eight directions) which was calculated from all the slope direction within the analysis unit. Slope number and density is the number of slope units within the analysis unit and the number of slopes per area unit within the analysis unit respectively. The terrain undulation is the value which designates the difference in elevation of the highest altitude point and the lowest altitude point within the analysis unit per unit area. 


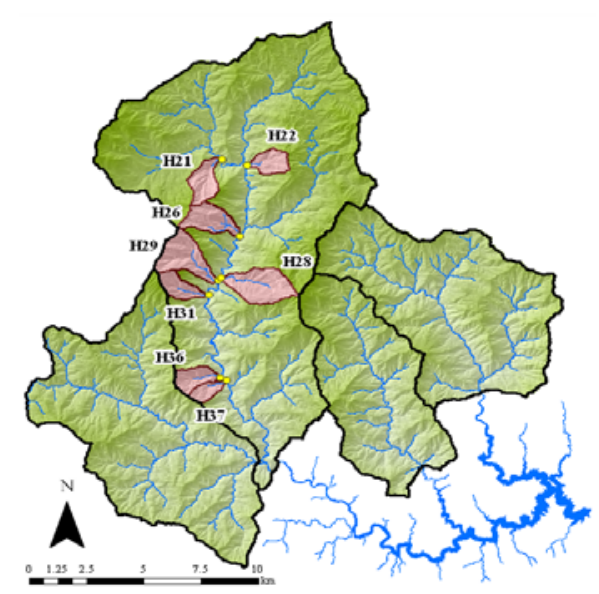

a) Watershed of fork in a river.

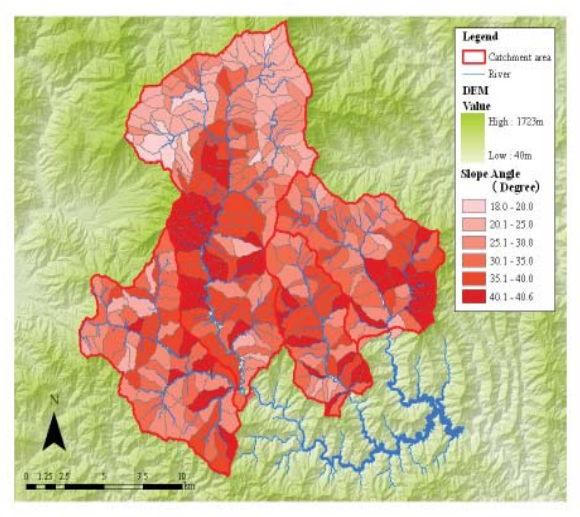

c) Mean of slope angle on rinpan

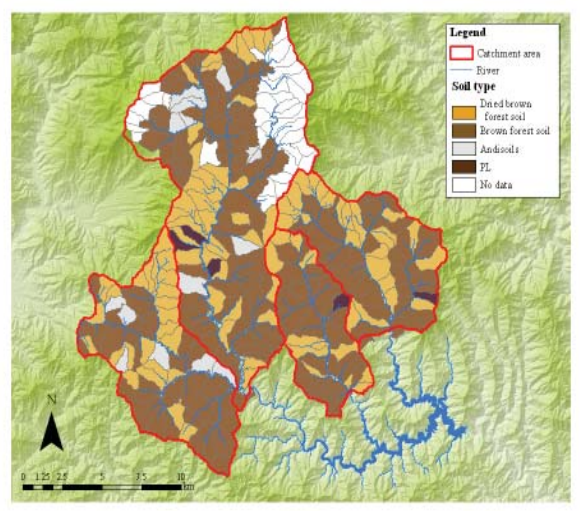

e) Distribution of soil type on rinpan.

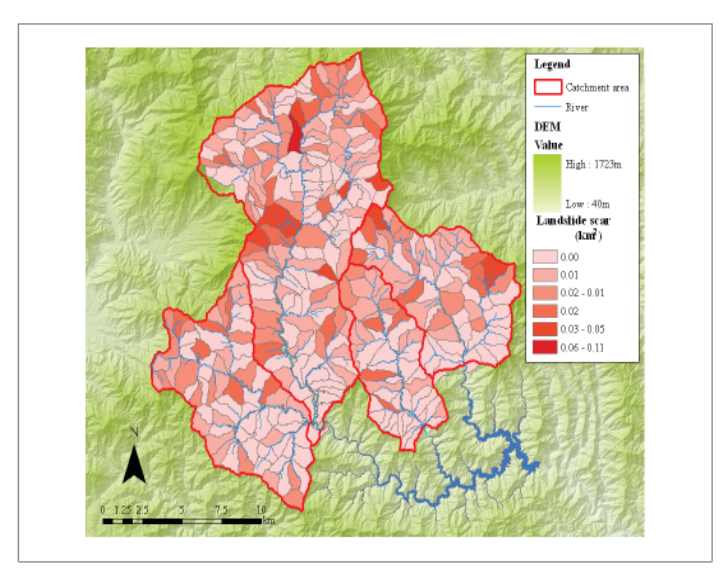

b) Area of landslide scar

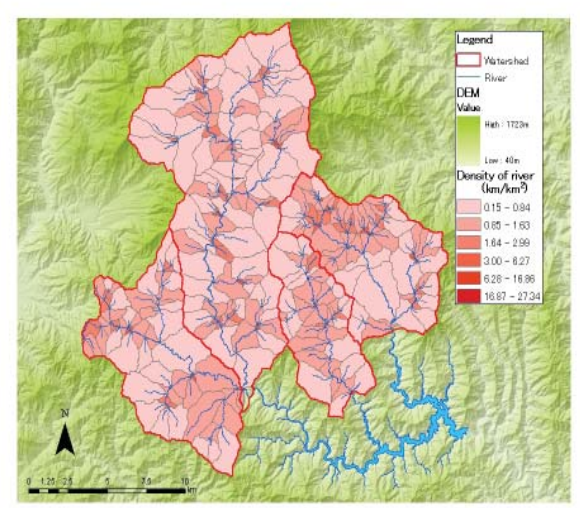

d) Density of river on watershed of fork in a river.

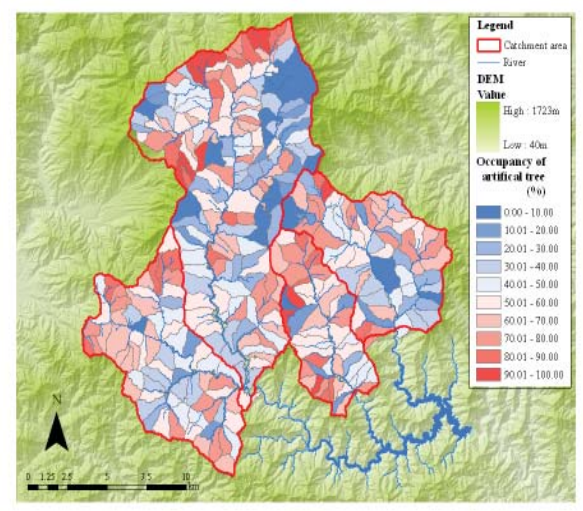

f) Occupancy of artificial forest on rinpan

Figure 2. Developed spatial data.

The other thematic data include geological soil type for the entire study area is illustrated and edaphic factor data, land cover factor data, and man-caused factor data. The identified $R$ important data for geologic and edaphic factor are geologic condition and soil type data. The in figure 2e, represented in area unit of rinpan. Rinpan is Japanese unit area which represents one type of forest section which is community of Syohan (one type of forest section) and is 
divided by natural landscape such as valleys, mountain ridges and rivers. A collection of rinpans forms a catchment.

Land cover factor includes land cover class, land cover change, and landslide scar. This information was extracted from the SPOT5 satellite data. The land cover class information was extracted by applying land use classification process to classify land cover into 7 classifications, namely forest, road, river, logging area, developed land, landslide scar, and bare land. Land cover change analysis was then conducted to grasp the information about the change of land use within the entire study area between February 2006 and November 2006. The identified land use change is from bare land to forest and vice versa, from forest to bare land. It was identified that from February to November 2006 there was a change in land use from bare land to forest at about $19.93 \mathrm{~km}^{2}$ or about 6.45 $\%$ of the total area.

Failed slope area has been regarded as one of the important factors which dictate the occurrence of suspended solids. Therefore, landslide scar is one factor that should be extracted from the satellite data, conducted by visual inspection. The total area of the landslide scar that could be identified is about $2.36 \mathrm{~km}^{2}$, or about $0.63 \%$ of the total study area. This number is the accumulation from the four watersheds at about $1.25 \mathrm{~km}^{2}(0.74 \%)$ for Hitotsuse, $0.38 \mathrm{~km}^{2}(0.49 \%)$ for Itaya, 0.31 $\mathrm{km}^{2}(0.53 \%)$ for Ogawa, and $0.42 \mathrm{~km}^{2}(0.55 \%)$ for Shiromi watershed. The percentage is the proportion to the total area of each watershed. The identified landslide scar areas then were represented into each slope unit. The result is the number of slopes which contain collapsed area, accounted for about 2575 or about $3.72 \%$ of the total area. This slope number is distributed within Hitotsuse, Itaya, Ogawa and Shiromi watersheds at about 1265 (3.88\%), $490(3.65 \%), 320(4.22 \%)$ and $500(4.39 \%)$ respectively.
Man-caused factor includes area of artificial forest and road density. Within the entire study area, forest area occupies about $91.60 \%$ of the total area. This is composed of natural forest at about $47.48 \%$ and artificial forest at about $44.12 \%$. The artificial forest is forest area which is planted with specific tree types and managed by local people for logging industry purpose. This area is distributed around the four watersheds with different coverage. Furthermore, the total length of the road networks is about $949.70 \mathrm{~km}$. This is distributed in Hitotsuse, Itaya, Ogawa and Shiromi watershed with road length at about $371.25 \mathrm{~km}, 250.52 \mathrm{~km}, 140.62 \mathrm{~km}$, and $187.27 \mathrm{~km}$ respectively. The density of road is the proportion between road length and its area. Therefore the average road density for each watershed is about $2.57 \mathrm{~km} / \mathrm{km}^{2}$ for Hitotsuse, $3.69 \mathrm{~km} / \mathrm{km}^{2}$ for Itaya, $3.65 \mathrm{~km} /$ $\mathrm{km}^{2}$ for Ogawa, and $3.22 \mathrm{~km} / \mathrm{km}^{2}$ for Shiromi watershed. In this research, the road density is calculated within catchment unit area.

The hydrological data includes rainfall, turbidity and river flow data. The historical river flow quantity $\left(\mathrm{m}^{3} / \mathrm{s}\right)$ at several stations as a result to rainfall from January $1^{\text {st }}$ until August $28^{\text {th }} 2007$ is represented in figure 3. During that time period, there were two peak rainfall intensities between April $6^{\text {th }}$ and April $30^{\text {th }}$ valued at about $30 \mathrm{~mm} /$ hour. The resulting river flow due to those two peak rainfall can be seen at Station H29 which shows highest river flow intensity with maximum value at about $9.8 \mathrm{~m}^{3}$ per second. Even though did not show a significant response to the peak rainfall intensity, Station 31 shows relatively constant river flow volume, with average value at above $1.4 \mathrm{~m}^{3}$ per second. For Stations H21, H26 and $\mathrm{H} 28$, even though they show a constant river flow value much less than Station $\mathrm{H} 29$ and H31, these stations show significant response to the two rainfall events. One of the reasons of the phenomenon is because the rainfall intensity was not evenly distributed over the whole area with the same intensity, concentrated around H29 and H31 catchments. 


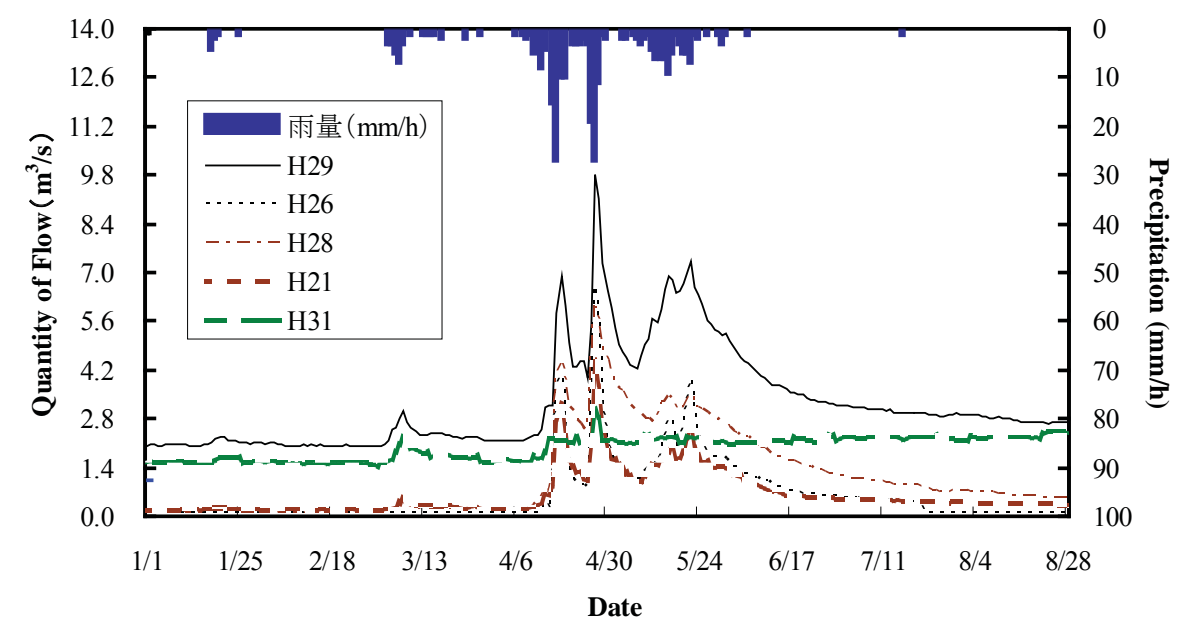

Figure 3. Precipitation and quantity of flow in observing watershed.

The turbidity amount as a response to the rainfall events is depicted in figure 4. This figure also represents the graph of predicted turbidity calculated by using tank model system. From the figure, it can be clearly seen that there is a positive correlation between the rainfall and observed turbidity. The rainfall events over the basin area has resulted in a significant turbidity quantity outflow as can be seen from the positive response of the turbidity value towards the rainfall data. In other words, the rainfall data variation throughout the graph is resembled by the turbidity data distribution along the time series. This positive strong correlation is verified by the correlation determination value at about 0.9 which was resulted from regression analysis. However, this is not the case for the predicted turbidity values. Even though the predicted turbidity values show the similar figures with the observed turbidity values, this figure is not good enough to judge the strong correlation between rainfall and predicted turbidity values. This is supported by the weak correlation determination value at about 0.56. Nonetheless, due to the high complexity of the hydrological model of the study area to be modeled, this result is considered good enough.

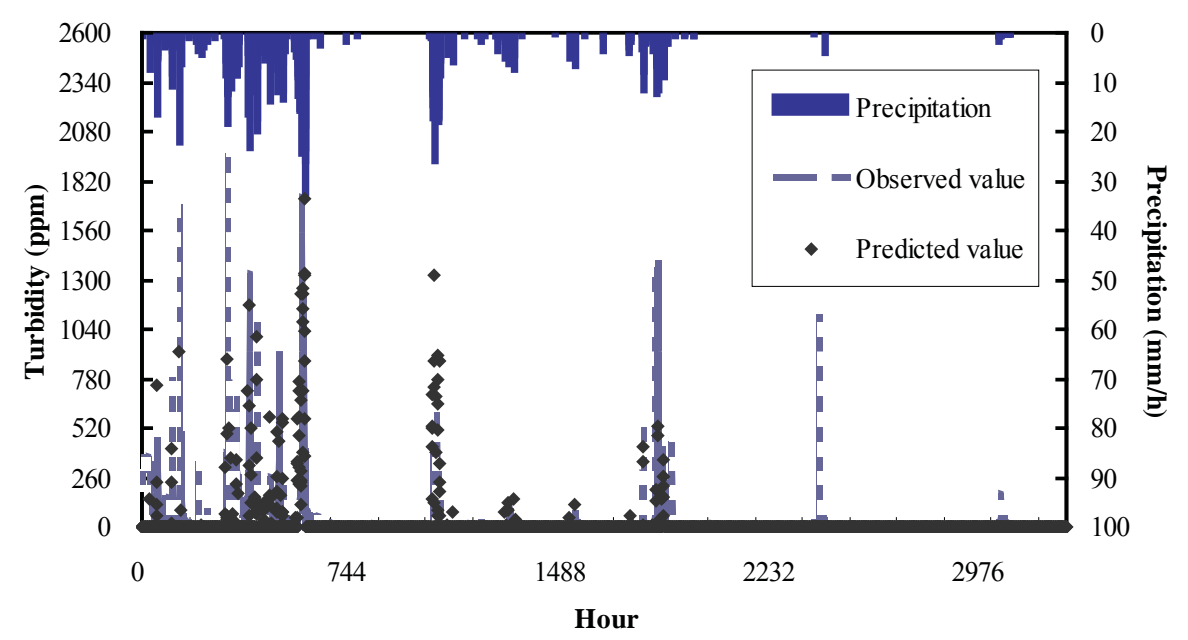

Figure 4. Precipitation and turbidity in observing watershed at station H36. 
The collected data were statistically evaluated using multiple regression analysis method. Since the general purpose of multiple regressions is to understand the relationship between several independent or predictor variables and a dependent or criterion variable, there are two objectives of the utilization of this method in this research. Firstly is to understand the important factors contributing to the occurrence of the suspended solids in the turbid water; and secondly is to be able to predict the total suspended solids quantity within the whole watershed. For this purpose, the mechanical factors are regarded as the independent variables, whereas turbidity is considered as dependent variable. The turbidity value used in this analysis is the turbidity values resulted from the hydrological tank model based on the constant intensity of precipitation input data at 10,20 and $30 \mathrm{~mm} / \mathrm{h}$. This scenario was applied in order to be able to measure the influence of the mechanical factors towards the resulting turbidity values at a certain rainfall event.

Table 3. Results of correlation analysis between suspended solids and factors

\begin{tabular}{|c|c|c|c|}
\hline \multirow{2}{*}{ Mechanical Factors } & \multicolumn{3}{|c|}{ Correlation determination coefficient } \\
\hline & Model 1 & Model 2 & Model 3 \\
\hline Drainage area $\left(\mathrm{km}^{2}\right)$ & $0.90 *$ & $0.91 *$ & $0.78 *$ \\
\hline River length (km) & 0.73 & 0.72 & $0.80 *$ \\
\hline River density $\left(\mathrm{km} / \mathrm{km}^{2}\right)$ & -0.07 & -0.07 & 0.17 \\
\hline Curvature of river & 0.60 & 0.61 & 0.68 \\
\hline Stream gradient & -0.05 & -0.09 & 0.08 \\
\hline $\begin{array}{l}\text { Average of slope angle } \\
\text { (degree) }\end{array}$ & -0.08 & -0.19 & -0.18 \\
\hline Number of slope & $0.88 *$ & $0.90 *$ & $0.77 *$ \\
\hline $\begin{array}{l}\text { Slope density (number/ } \\
\mathrm{km}^{2} \text { ) }\end{array}$ & 0.52 & 0.60 & 0.50 \\
\hline $\begin{array}{l}\text { Terrain undulation }(\mathrm{m} / \\
\left.\mathrm{km}^{2}\right)\end{array}$ & $-0.84 *$ & $-0.82 *$ & -0.67 \\
\hline Road density $\left(\mathrm{km} / \mathrm{km}^{2}\right)$ & -0.27 & -0.18 & -0.24 \\
\hline $\begin{array}{l}\text { Area of artificial forest } \\
\left(\mathrm{km}^{2}\right)\end{array}$ & $0.90 *$ & $0.91 *$ & $0.76 *$ \\
\hline $\begin{array}{l}\text { Area of landslide scar } \\
\left(\mathrm{km}^{2}\right)\end{array}$ & $0.78 *$ & 0.75 & $0.89 *$ \\
\hline $\begin{array}{l}\text { Occupancy of landslide } \\
\text { scar }(\%)\end{array}$ & 0.69 & 0.63 & $0.80 *$ \\
\hline Number of failed slope & $0.74 *$ & 0.71 & $0.87 *$ \\
\hline Are a of failed slope $\left(\mathrm{m}^{3}\right)$ & 0.69 & 0.66 & $0.83 *$ \\
\hline Bare land $\left(\mathrm{km}^{2}\right)$ & 0.61 & 0.64 & $0.76^{*}$ \\
\hline
\end{tabular}

Table 3 depicts the correlation analysis results between the suspended solids and mechanical factors. Correlation determination coefficients which determine the correlation strength between the two variables are grouped in model 1, 2 and 3. Model 1, model 2 and model 3 are the suspended solids quantity which was predicted based on input precipitation data of $10 \mathrm{~mm} / \mathrm{h}, 20 \mathrm{~mm} / \mathrm{h}$ and $30 \mathrm{~mm} / \mathrm{h}$ respectively. The starred number shows the 
strong correlation between the variables that varies between model 1 , model 2 and model 3 . Based on these values, the mechanical factors which are highly correlated to the suspended solids outflow quantity then were selected for the multiple regression analysis, to find the most significant mechanical factors towards the suspended solids outflows and also to develop a multi regression equation for suspended solids outflow prediction.

Table 4 depicts the partial regression coefficient of each mechanical factor of model 1, model 2 and model 3, which were resulted from different scenarios. Each scenario involves different combination of mechanical factors when conducting multiple regression analysis. For this purpose, the selection of the mechanical factors to be included in the analysis is based on the information on table 3 ; i.e. only the factors which have strong correlation with the suspended solids outflow would be included in the analysis. Therefore there are several scenario of analysis to be conducted in order to be able to find the most significant factors. From the model 1, scenario 1 gives the best result as is indicated by the highest value of coefficient of determination at about 0.98 . This scenario reveals the fact that drainage area, terrain undulation and area of landslide scar have significant contribution in determining the suspended solids quantity. For model 2, scenario 1 takes account of drainage area and terrain undulation as important factors. Furthermore, model 3 has put scenario 1 with area of artificial forest and area of landslide scar factors as the best result.

Table 4 Result of multiple regression analysis (standardized partial regression coefficient)

\begin{tabular}{|c|c|c|c|c|c|c|c|c|c|}
\hline \multirow{2}{*}{$\begin{array}{l}\text { Mechanical } \\
\text { Factor }\end{array}$} & \multicolumn{3}{|c|}{ Model 1} & \multicolumn{2}{|c|}{ Model 2} & \multicolumn{4}{|c|}{ Model 3} \\
\hline & Sce 1 & Sce 2 & Sce 3 & Sce 1 & Sce 2 & Sce 1 & Sce 2 & Sce 3 & Sce 4 \\
\hline $\begin{array}{l}\text { Drainage area } \\
\left(\mathrm{km}^{2}\right)\end{array}$ & 0.42 & & & 0.65 & & & & & 0.59 \\
\hline $\begin{array}{l}\text { River length } \\
(\mathrm{km})\end{array}$ & & & & & & & 0.29 & & -0.05 \\
\hline $\begin{array}{l}\text { Number of } \\
\text { slope }\end{array}$ & & 0.40 & & & 0.63 & & & & \\
\hline $\begin{array}{l}\text { Slope density } \\
\left(\text { number } / \mathrm{km}^{2}\right) \\
\text { Terrain } \\
\text { undulation } \\
\left(\mathrm{m} / \mathrm{km}^{2}\right) \\
\text { Road density } \\
\left(\mathrm{km} / \mathrm{km}^{2}\right)\end{array}$ & -0.37 & -0.38 & & -0.35 & -0.38 & & & & \\
\hline $\begin{array}{l}\text { Area of } \\
\text { artificial forest } \\
\left(\mathrm{km}^{2}\right)\end{array}$ & & & 0.68 & & & 0.44 & 0.46 & 0.51 & \\
\hline $\begin{array}{l}\text { Area of } \\
\text { landslide scar } \\
\left(\mathrm{km}^{2}\right) \\
\text { Occupancy of }\end{array}$ & 0.39 & 0.41 & 0.47 & & & 0.69 & & & \\
\hline $\begin{array}{l}\text { landslide scar } \\
(\%)\end{array}$ & & & & & & & & 0.41 & 0.60 \\
\hline $\begin{array}{l}\text { Are a of failed } \\
\text { slope }\left(\mathrm{m}^{3}\right)\end{array}$ & & & & & & & 0.46 & & \\
\hline $\begin{array}{l}\text { Coefficient of } \\
\text { determination }\end{array}$ & 0.983 & 0.981 & 0.961 & 0.825 & 0.821 & 0.927 & 0.923 & 0.903 & 0.786 \\
\hline
\end{tabular}

Sce stands for Scenario. 
From the selected scenarios, the selected mechanical factors which significantly contribute to the suspended solids outflow vary from model 1 , model 2 and model 3. Area of landslide scar, for example, is regarded as important factor in model 1 and model 3, whereas drainage area and terrain undulation factors are essential in model 1 and 2. The ideal situation is that the selected mechanical factors are the same in all models. Yet, it is difficult to achieve this ideal result since there are many aspects in the research steps contribute to the final results. One of the aspects is the hydrological model used for turbidity prediction. Necessary measures need to be carried out to refine and to improve its performance.

For the purpose of turbidity prediction for the whole watershed area, regression equation was constructed. Equation (1) is the multiple regression equation for the model 3 . As a result, for the rainfall event of $30 \mathrm{~mm} / \mathrm{h}$, the estimated turbidity outflow is:

Predicted suspended solids $=21.875 \mathrm{x}$ (area of landslide scar) +1.212 x (Area of artificial forest) -0.45
From comparison of the coefficient of each term in this equation, it is notable that area of landslide scar is more important for predicting suspended solids than the area of artificial forest.

\section{Conclusion}

An attempt to understand the influential factors in relation to the suspended solids currents within the river water in Hitotsuse area has been demonstrated in this research. The spatial data extraction process which was conducted within GIS spatial analysis could be conducted effectively. Furthermore, by applying multivariate analysis on the three models which were based on three different precipitation intensities $(10 \mathrm{~mm} / \mathrm{h}, 20 \mathrm{~mm} / \mathrm{h}$ and $30 \mathrm{~mm} / \mathrm{h}$ ), the important factors which dictate the suspended solids currents could be recognized. These identified mechanical factors vary from model 1 , model 2 and model 3. However, based on these findings, it can be concluded that in general, the important mechanical factors are drainage area, terrain undulation, area of landslide scar, and area of artificial forest.

\section{References}

Ahearn, D.S., Sheibley, R.S., Dahlgren, R.A., Anderson, M., Jonson, J., and Tate, K.W. (2005). Land use and land cover influence on water quality in the last free-flowing river draining the western Sierra Nevada, California. Journal of Hydrology, 313, 234-247.

Bustamante, J., Pacios, F., Di'az-Delgado, R. and Aragone's, D. (2008). Predictive models of turbidity and water depth in the Do nana marshes using Landsat TM and ETMt images. Journal of Environmental Management, 1e 7

Chen, Z., Hu, C., Muller-Karger, F. (2007). Monitoring turbidity in Tampa Bay using MODIS/ Aqua 250-m imagery. Remote Sensing of Environment 109 (2007) 207-220.

Chikita, K. and Okumura, Y. (1990). Dynamics of turbidity current measured in Katsurazawa reservoir, Hokkaido, Japan. Journal of Hydrology, 117 (1990) 323-338 323

Foltza, R. B., Yanoseka, K. A. and Brownb, T. M. (2007). Sediment concentration and turbidity changes during culvert removals. Journal of Environmental Management, doi:10.1016/j. jenvman.2007.01.047

Heyes, A., Miller, C., \& Mason, R. P. (2004). Mercury and methylmercury in Hudson River sediment: Impact of tidal re-suspension on partitioning and methylation. Marine Chemistry, 90(1-4), 75-89. 
Hill, A.R. (1981). Stream phosphorus exports from watersheds with contrasting land uses in southern Ontario. Water Resources Bulletin, 17, 627-634.

Lawler, D. M., Petts, G. E., Foster I. D. L., and Harper, S. (2006). Turbidity dynamics during spring storm events in an urban headwater river system: The Upper Tame, West Midlands, UK. Science of the Total Environment, 360 (2006) 109- 126

Li, S., Xu, Z., Cheng, X., and Zhang, Q. (2008). Dissolved trace elements and heavy metals in the Danjiangkou Reservoir, China. Environmental Geology. doi:10.1007/s00254-0071047-5.

Ngoye, E., and Machiwa, J.F. (2004). The influence of land use patterns in the Ruvu river watershed on water quality in the river system. Physics and Chemistry of the Earth 29, 1161-1166.

Osawa, K., Sakai, K. and Shimada, M. (2003). Construction of the suspended sediment runoff model for agricultural basins. In: Williams JD and Kolpin DW (eds). AWRA 2003 Spring Specialty Conference. Kansas, KA.

Pavanelli, D. and Bigi, A. (2005). A new indirect method to estimate suspended sediment concentration in a river monitoring program. Biosystems Engineering (2005) 92 (4), 513520 .

Pirmez, C. and Imran, J. (2003). Reconstruction of turbidity currents in Amazon Channel. Marine and Petroleum Geology, 20 (2003) 823-849

Sakai, K., Osawa, K. and Yoshinaga, A. (2005). Development of suspended sediment concentration (SSC) analysis model and its application with multi-objective optimization. Paddy Water Environ (2005) 3: 201-209

Sliva, L., and Williams, D. D. (2001). Buffer zone versus whole catchment approaches to studying land use impact on river water quality. Water Research, 35, 3462-3472.

Smart, R.P., Soulsby, C., Neal, C., Wade, A., Cresser, M.S., Billett, M.F., Langan, S.J., Edwards, A.C., Jarvie, H.P., and Owen, R. (1998). Factors regulating the spatial and temporal distribution of solute concentrations in a major river system in NE Scotland. The Science of the Total Environment, 221, 93-110.

Stech1, J., Alcântara1, E., Novo1, E., Shimabukuro1, Y. and Barbosa, C. (2007). Turbidity in the Amazon floodplain assessed through a spatial regression model applied to fraction images derived from MODIS/Terra. IEEE. Downloaded on October 5, 2008 at 22:50 from IEEE Xplore.

Susfalk, R. B., Fitzgerald, B. and Knust, A. M. (2008). Characterization of Turbidity and Total Suspended Solids in the Upper Carson River, Nevada. DHS Publication No. 41242, January 2008.

Turner, R.E., Rabalais, N.N. (2003). Linking landscape and water quality in the Mississippi River Basin for 200 years. Bioscience, 53, 563-572. 